IIS FA:

RECONO GOR

\title{
POWDER METALLURGY AT SAVANNAH RIVER LABORATORY
}

\author{
H. B. PEACOCK
}

DECEMBER 1978

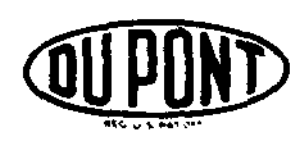

SAVANNAH RIVER LABORATORY AIKEN, SOUTH CAROLINA 29801 


\section{DISCLAIMER}

This report wes prepared es an eccount of work sponsored by the Unleed States Government. Neither the United States nor the Unlted Steter Departmant of Enaroy, nor any of their implovees, make any warranty. exprew or implied, or eseumes any legal liablifty or responsibility for the eccuracy, complateness, or usefulnoss of any information, apparatus, product, or procwes disclosed, or represents that tis use would not infringe privately owned rlohts. Reference hereln to any epecific commercial pro. duet, procese, or enrvice by trade name, mark, manufecturer, or otherwise does not necesearily constitute or imply lts ondoreament, recommendation, or fevoring by the United Stetes Government or eny egency therreof. The vlews and opinione of authore expresed herein do not necesearily state or reflect thos of the Unlted States Govornment or any apency thereof.

Printed in the United States of Amorice

\section{Aveliable from}

National Technical Information Service U. S. Dopertment of Commerce 5285 Port Roy Gol Road

Springfield, Virginia 22161

Price: Printed Copy $\$ 4.00$; Microfich $\$ 3.00$ 
DP-1524

UC-80

\title{
POWDER METALLURGY AT
} SAVANNAH RIVER LABORATORY

\author{
H. B. PEACOCK
}

Approved By

G.F. MERZ, RESEARCH MANAGER

REACTOR ENGINEERING DIVISION

DECEMBER 1978

E. I. DU PONT DE NEMOURS AND COMPANY SAVANNAH RIVER LABORATORY AIKEN, SOUTH CAROLINA 29801

PREPARED FOR THE U.S. DEPARTMENT DF ENERGY UNDER CONTRACT AT(07-2)-1 
Development of a powder metallurgical process for the manufacture of reactor grade fuel tubes is being carried out at the Savannah River Laboratory (SRL). Using the $\mathrm{P} / \mathrm{M}$ technology, cores were isostatically compacted with $100 \mathrm{wt} \% \mathrm{U}_{3} \mathrm{O}_{8}$ and coextruded tubes fabricated which contain up to $280 \%$ cores clad with aluminum.

Irradiation tests were completed for tubes with up to 59 wt \% oxide. Post-irradiation inspection showed no significant swelling for $40 \%$ burnup. Thermal testing of sections from irradiated tubes showed that the threshold temperature for blister formation increased as the fission density of oxide decreased.

Procedures are discussed for making PM cores and extruded tubes at SRL. Both laboratory and full-scale tests are presented. 
CONTENTS

Introduction 5
Discussion 5
Tube Fabrication Process 5
Process Conditions for Fabricating $\mathrm{P} / \mathrm{U}$ Fue1 Billet Cores 7
Charge Calculations 12
Fabrication of Sma11 Scale $\mathrm{U}_{3} \mathrm{O}_{8}-\mathrm{Al}$ Fuel Tubes 12
Measurements of Extrusion Forces 15
Cladding Thickness Determination 16
P/U Irradiation Tests at SRP 16
Evaluation of Irradiated P/U Fuel 16
Conclusions 19
References 20




\section{LIST OF FIGURES}

1 Cross Section of a Fuel Assembly 6

2 Block Diagram for P/M Core Fabrication 7

3 Particle Size Distribution for Roll Ground $\mathrm{U}_{3} \mathrm{O}_{8}$ and 108 Aluminum Powder 9

4 Powder Pre-Blend and Seiving Apparatus 10

5 Test of Modified Tumbling Mixer 11

6 Small-Scale and Full-Size Outer Fuel Tubes 14

7 Effect of $\mathrm{U}_{3} \mathrm{O}_{8}$ Content, Extrusion Tooling Temperature and Half the Die Cone Angle on Tube Quality 15

8 Effect of Tooling Temperature and $\mathrm{U}_{3} \mathrm{O}_{3}$ Concentration on Extrusion Force Required 16

9 Temperatures Required for Blister Formation on Irradiated Fuel Tubes with $\mathrm{U}_{3} \mathrm{O}_{8} \mathrm{P} / \mathrm{M}$ Cores $240 \%$ Burnup 19

\section{LIST OF TABLES}

1 SRP Irradiation of $\mathrm{P} / \mathrm{M}$ Fuel Tubes 18 


\section{POWDER METALLURGY DEVELOPMENT AT SRL}

\section{INTRODUCTION}

The Savannah River Laboratory (SRL) is developing a powder metallurgy ( $\mathrm{P} / \mathrm{M})$ process for manufacturing reactor-grade fue 1 tubes containing high wt $\% \mathrm{U}_{3} \mathrm{O}_{8}-\mathrm{Al}$ cores clad with 8001 aluminum. The $\mathrm{P} / \mathrm{M}$ cores are made by isostatic compaction. They are assembled in billets, outgassed, and hot-extruded using conventional coextrusion techniques. ${ }^{1}$ Cores have been compacted with up to $100 \%$ enriched $\mathrm{U}_{3} \mathrm{O}_{8}$ and tubes extruded with up to $80 \mathrm{wt} \%$. oxide cores.

Irradiation tests have been made using $P / M$ core tubes in the Savannah River reactors. These tubes contained $\mathrm{U}_{3} \mathrm{O}_{\mathrm{B}}$ concentrations up to 59 wt \% and no significant swelling or blistering occurred. The tubes were irradiated to $\sim 40 \%$ burnup or $1.6 \times 10^{21}$ fissions/cc of core.

This report discusses both sma11-scale and production tests for high-density $\mathrm{P} / \mathrm{M}$ fuel development. The purpose of the $\mathrm{P} / \mathrm{M}$ development program at SRL is to:

- determine the maximum $\mathrm{U}_{3} \mathrm{O}_{8}$ content that can be fabricated into thin wall tubes,

- irradiate high-content tubes to high burnup and assess irradiation and dimensional stability,

- continue metal forming studies for extrusion and drawing, and

- evaluate hydrostatic extrusion and hydrostatically assisted drawing of $\mathrm{P} / \mathrm{M}$ core tubes.

\section{DISCUSSION}

\section{Tube Fabrication Process}

Production fuel assemblies have a $12.5-\mathrm{ft}$-1ong core and generally consist of 3 concentric tubes as shown in Figure 1 . The ID and OD of the assembled tubes range from about 1.75 to 3.75 in., respectively. SRP fuel tubes operate at low temperature and use aluminum to facilitate separations. However, the basic technology may be applicable for other type fuel tubes and materials, i.e., stainless steel and Zircaloy. 


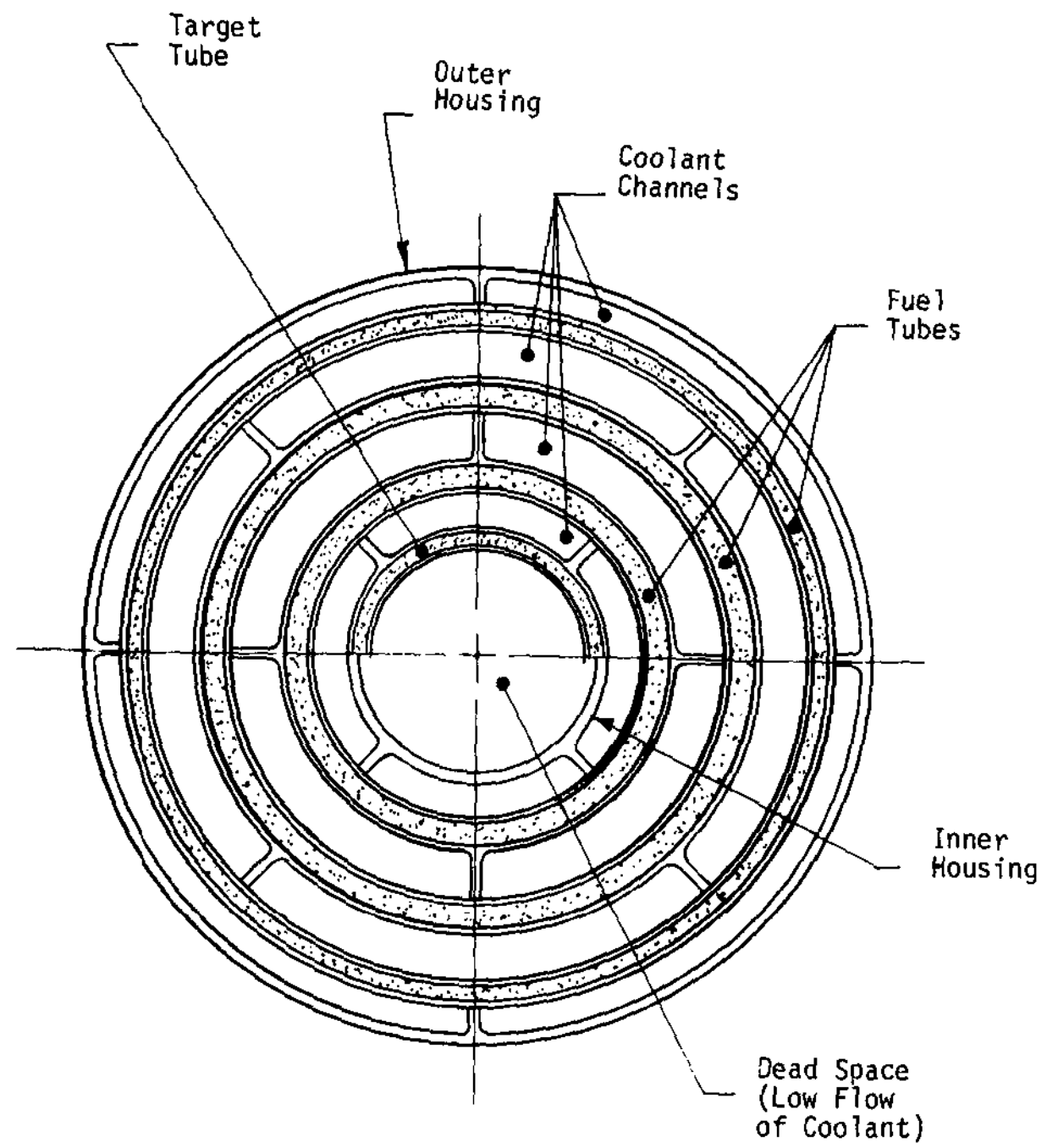

FIGURE 1. Cross Section of A Fuel Assembiy

Process steps are similar to those used commercially for aluninum tube manufacture. The basic process is divided into fabrication and quality control steps. Each tube is carefully inspected to ensure quality fuel to prevent activity releases to the moderator during irradiation. Determination of the core homogeneity is accomplished using the Fuel Distribution Analyzer (FDA) and the Nuclear Test Gage (NTG). The FDA is an instrument which uses $x$-rays to determine the relative concentration of uranium or $\mathrm{U}_{3} \mathrm{O}_{B}$ along the length of the tube. High fuel concentrations can cause local heating and burnout of the cladding. The NTG is a small subcritical reactor that measures the reactivity of the tube in $2-\mathrm{ft}$ increments. 


\section{Process Conditions for Fabricating $P / M$ Fuel Billet Cores}

These steps are used to make $P / M$ billet cores for reactor fuel tubes at SRP and are summarized in the following order:

1) Oxide firing and grinding

2) Blending of $\mathrm{U}_{3} \mathrm{O}_{8}$ and aluminum powders

3) Isostatic compaction of $P / M$ billet cores

4) Extrusion of fuel tubes

5) In-line recycle of reject cores and tubes

Figure 2 shows the flow of material through the overall operation, integrated with the in-1ine recycle.

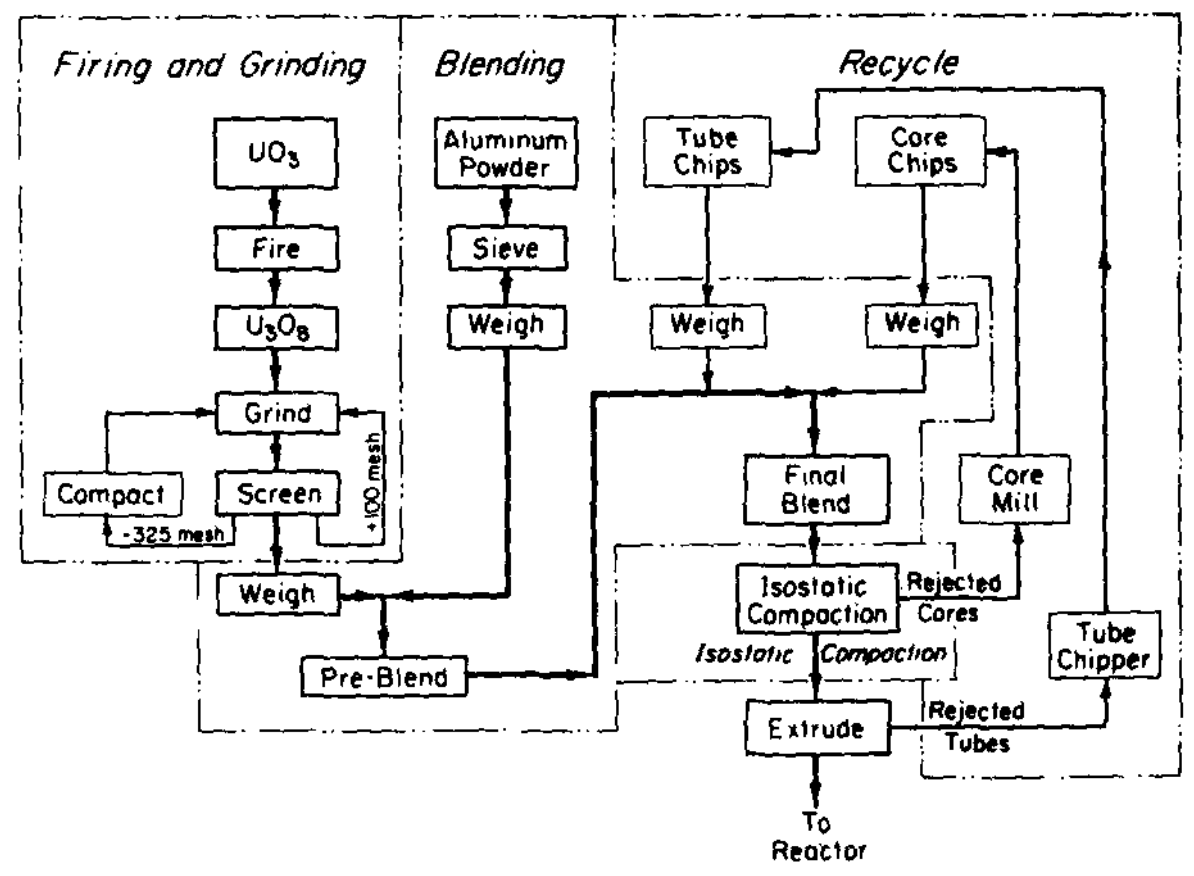

FIGURE 2. Block Diagram for P/M Core Fabrication 


\section{Oxide Firing and Grinding}

$\mathrm{UO}_{3}$ is the feed material for the $\mathrm{U}_{3} \mathrm{O}_{8}-\mathrm{Al}$ compact core process. It is calcined to $\mathrm{U}_{3} \mathrm{O}_{2}$ in resistance-heated box furnaces at $800^{\circ} \mathrm{C}$ for 6 hours in nitrogen, then air cooled to ambient temperature. Oxide is fired in Incone $600^{*}$ pans of critically safe configuration to prevent nuclear criticality incidents. The as-fired $\mathrm{U}_{3} \mathrm{O}_{8}$ is ground and sieved to provide powder of the desired particle size distribution. Oversize material from grinding is reground while excess undersize material is compacted and reground.

Oxide particle size must be controlled for three reasons:

- Maximum particle size must be limited to avoid large hard particles that can penetrate the tube cladding and/or cause hot spots sufficient to produce melting during irradiation. The maximum particle size is 100 US standard mesh (149 $\mu)$.

- The quantity of -325 mesh $(<44 \mu)$ particles is restricted for radiation stability because the retention of fission gases is less in small particles.

- The particle size distribution $<100$ mesh is controlled to match the size distribution of the aluminum powder to obtain a blend with acceptable homogeneity.

$\mathrm{U}_{3} \mathrm{O}_{8}$ is ground in a commercial roll grinder modified to provide precise roll gap adjustment, variable speed, minimal holdup of powder in housing and to minimize dust release. $\mathrm{U}_{3} \mathrm{O}_{8}$ is fed into the grinder by a separate vibratory feeder at a uniform rate and distributed across the entire width of the rolls. Ground $\mathrm{U}_{3} \mathrm{O}_{8}$ is discharged directly into a commercial vibrating-screen separator. Powder is discharged from the separator into critically safe containers. Oversize material is recycled directly through the grinder. If excess -325 mesh material is produced from one batch, it is blended into batches that have low -325 mesh contents. If all excess -325 mesh material cannot be utilized in this manner, it is compacted and reground.

The particle size distribution depends on the properties of the oxide, the grinding conditions, such as roll gap and pressure, roll speed, and feed rate. Grinding conditions were developed to produce a maximum of -100 mesh powder per pass through the grinder and at the same time maintain a maximum of $40 \%-325$ mesh material. The particie size distribution of the $-100 /+325$ mesh material produced using these conditions does not exactly match that of the aluminum powder (Figure 3); however, the matchup is close enough that it blends adequately with the aluminum.

*'Trademark of International Nickel 


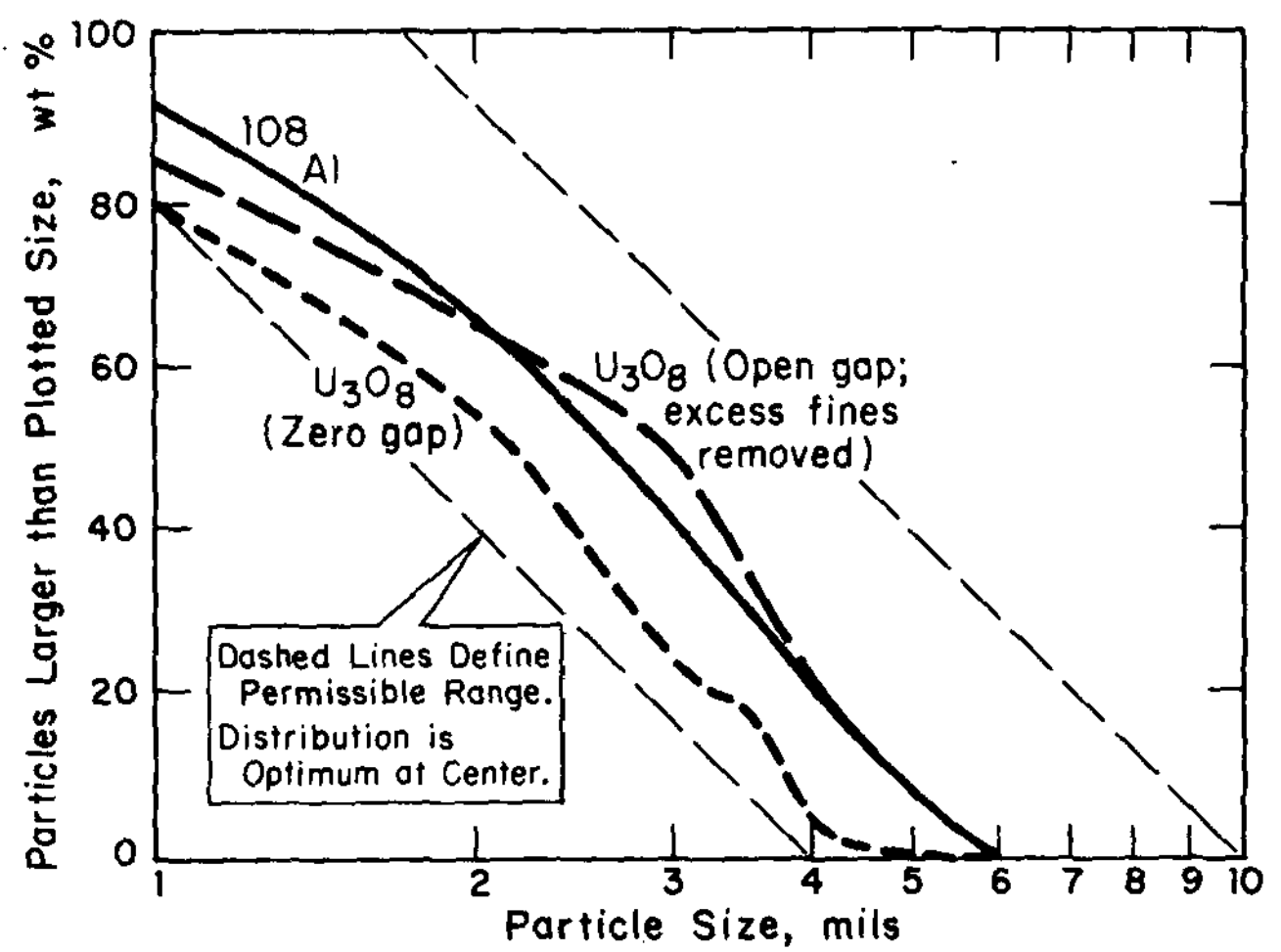

FIGURE 3. Particle Size Distribution for Roll Ground $\mathrm{U}_{3} \mathrm{O}_{B}$ and 108 Aluminum Powder

\section{Blending of $\mathrm{U}_{3} \mathrm{O}_{8}$ and Aluminum Powders}

The $\mathrm{U}_{3} \mathrm{O}_{8}$ is uniformly blended with aluminum powder to produce material for the billet fabrication process. To overcome the tendency of fine $\mathrm{U}_{3} \mathrm{O}_{8}$ powder to agglomerate and segregate, preblending and sieving steps were incorporated. After a 5minute preblend in a horizonta1 drum blender, the powder is transferred through an 80 mesh vibrating screen (Figure 4) into the final blend container. This final screening breaks down the agglomerated $\mathrm{U}_{3} \mathrm{O}_{8}$ in the feed, and ensures that no large particles get into the final blend. Therefore, the aluminum powder in the mixture hinders any reagglomeration of $\mathrm{U}_{3} \mathrm{O}_{8}$. The drum and screen are then removed, the tumbling blender is closed and adjusted to horizontal blending attitude, and the feed is tumbled to obtain a uniform mixture. Then the compaction mold assembly is attached to the open blender and the rotating blender is inverted to transfer the feed into the mold. The blend in the mold is then vibrated to uniform prepressing density ( $\sim 55 \%$ of solid density), the mold is sealed, and the powder is subjected to isostatic compaction to $\sim 80 \%$ of solid density. 


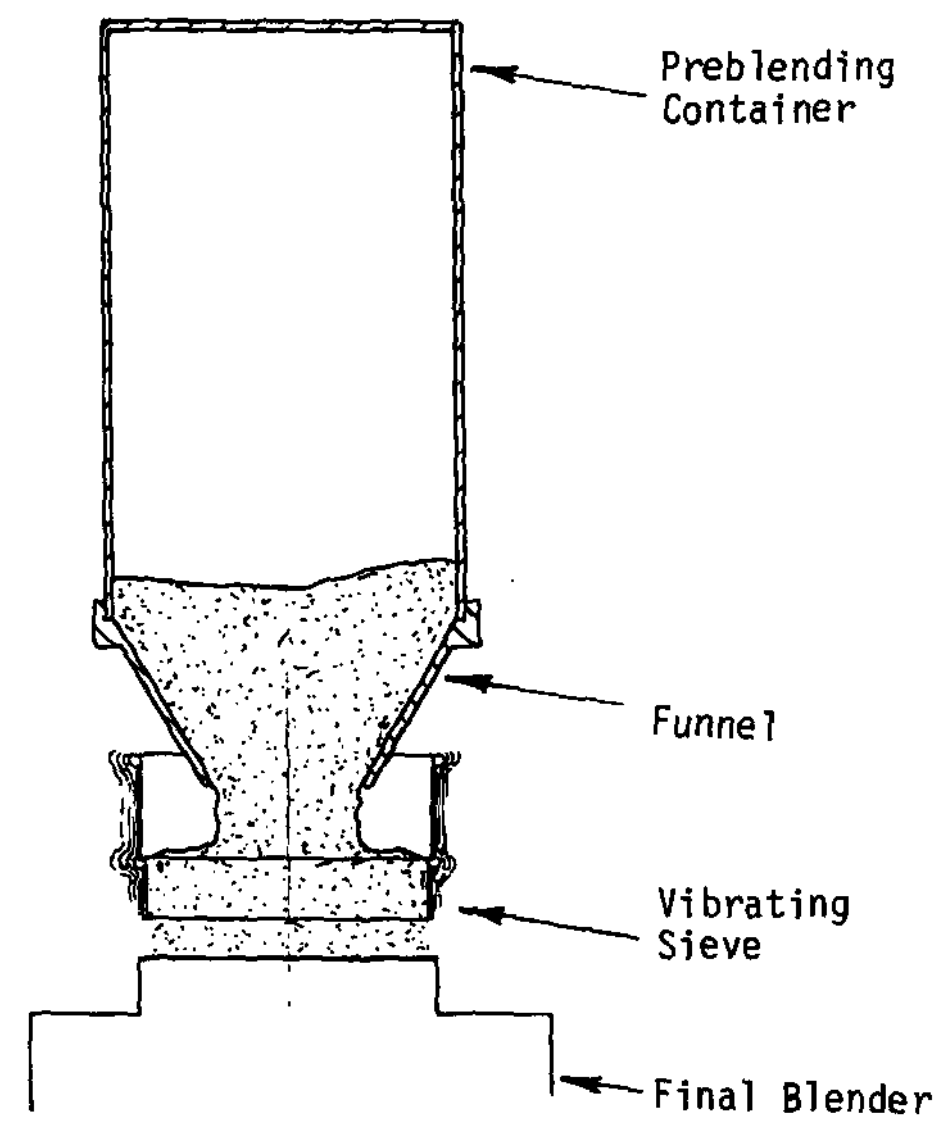

FIGURE 4. Powder Pre-Blend and Sieving Apparatus

The $\mathrm{U}_{3} \mathrm{O}_{8}$ and aluminum powders tend to segregate after blending because of the differences in density $\left(8.4 \mathrm{~g} / \mathrm{cm}^{3}\right.$ for $\mathrm{U}_{3} \mathrm{O}_{B}$ and $2.7 \mathrm{~g} / \mathrm{cm}^{3}$ for $\mathrm{Al}$ ) and in particle size distribution of the two powders. Also, segregating mechanisms such as pouring and vibrating must be controlled closely. Blended powder is transferred from the mixer to the mold (which is connected directly to the mixer) by tilting the mixer as it rotates and tumbles the powder directly into the mold. Mold vibration, which is necessary to produce uniform mold-to-mold powder density, is limited to 20 seconds to reduce potential segregation.

Tests with Type 101 aluminum powder and ${ }^{235} \mathrm{U}$-depleted $\mathrm{U}_{3} \mathrm{O}_{8}$ powder compared the efficiency of the tumbling blender with that of a standard horizontal drum blender. The basic difference is that the tumbling blender has 1-in.-diameter pins which increase shear mixing. The particle size distribution of the $\mathrm{U}_{3} \mathrm{O}_{8}$ was varied from a typical as-ground distribution to all -325 mesh. 
Twelve samples, each equivalent in blend volume to a 0.25 by 0.25-in. section of extruded core, were taken at specified intervals from the blend. A thieving procedure was developed to minimize sampling errors. When a thief is inserted into a bed of mixed powders, it distorts the mixture and may result in collection of a nonrepresentative sample. ${ }^{2}$ In this investigation, the thief was rotated into the powders during the final blending step giving less bed distortion. The sample was collected beginning at the surface of the blend. $\mathrm{U}_{3} \mathrm{O}_{8}$ content was determined by neutron activation with estimated accuracy of \pm 0.5 wt $\% \mathrm{U}_{3} \mathrm{O}_{8}$.

Results for the tumbling blender and a standard horizontal blender showed the superiority of the tumbling blender for blending fine ( -325 mesh) powders. The analysis of the data was carried out by expressing the coefficient of variation (CV) as a function of the number of blender revolutions. The coefficient of variation is defined as the standard deviation of the thieved samples expressed as a percentage of the mean oxide content. For a 26 wt $\%$ mixture, $\mathrm{CV}$ for the tumbling blender was $50 \%$ less than the value for the standard blender and remained less with an average value of $2.5 \%$ after 200 revolutions (10 minutes). The $\mathrm{CV}$ for a 40 wt $\% \mathrm{U}_{3} \mathrm{O}_{8}-\mathrm{Al}$ blend with the specified oxide particle size distribution is shown in Figure 5 for the tumbling blender. After 100 revolutions, $\mathrm{CV}$ averaged about $5 \%$, which corresponds to $10 \%$ variation in uranium content per $0.25 \times 0.25$ in. section of the core at $95 \%$ confidence.

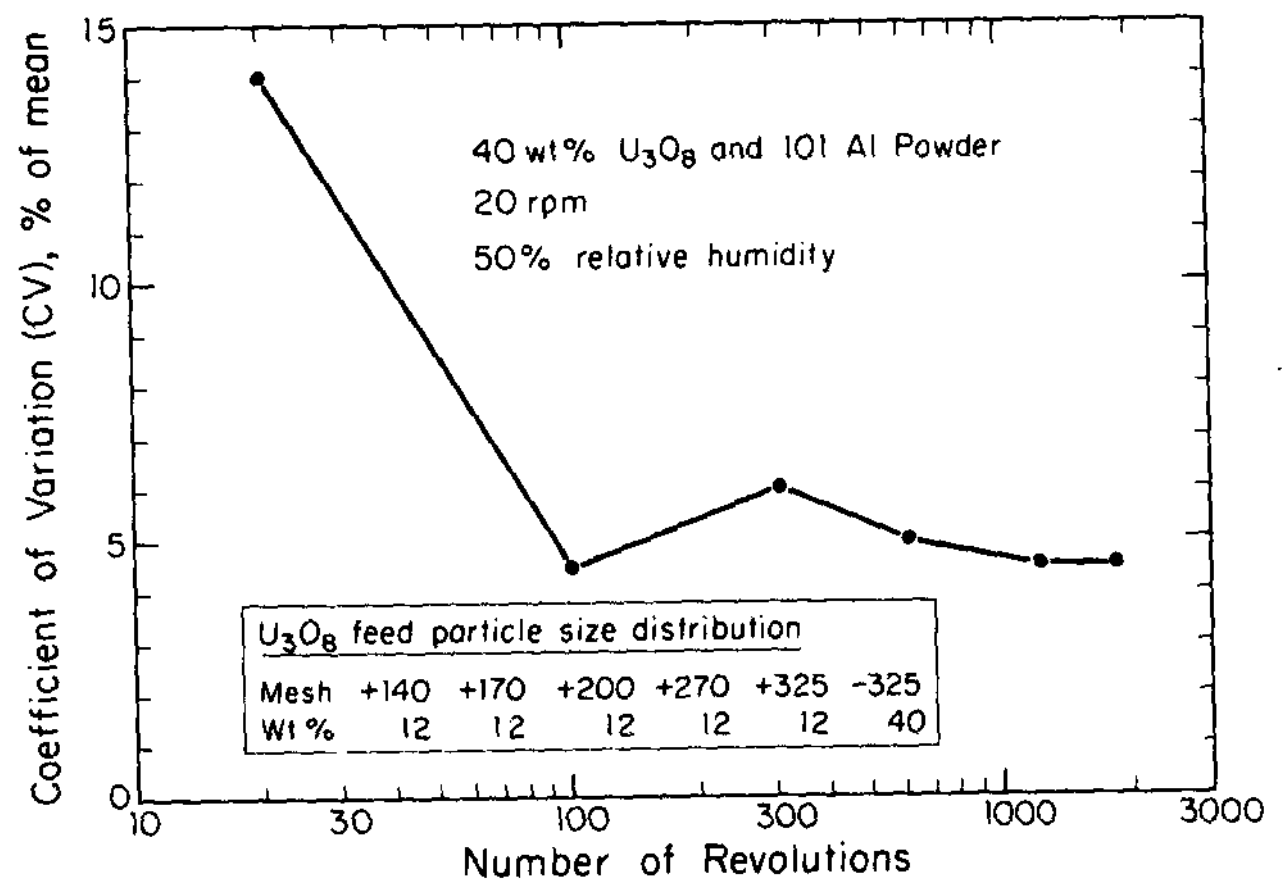

FIGURE 5. Test of Modified Tumbling Mixer 


\section{Isostatic Compaction of $P / M$ Billet Cores}

Isostatic compaction, in which powder is sealed in a 0.5-in.thick elastomeric urethane mold and compacted under high fluid pressure, is used to form the $P / M$ cores. Urethane bag life has not been determined, but over 150 cores have been made from a single bag with no indications of wear. Cores made by this process slide easily from the depressurized mold; they have uniform density and the total uranium content can be controlled precisely. Although the OD of the core does not have the dimensional uniformity of cast or machined cores because of the elasticity of the mold, the compact is fully suitable for direct insertion in the billet assembly. The core ID, formed by a steel mandrel, is always the same. Variations in core wall thickness of $\pm 0.03 \mathrm{in}$. (average wall thickness $1.4 \mathrm{in.)}$ and variations in OD of \pm about 0.05 in. (average OD 7.4 in.) have been measured. These variations correspond to less than $3 \%$ variation in thickness of the extruded core.

Cores made in a mold with a cylindrical ID tend to have an hourglass shape because of end restraint by the mold. To compensate for this effect, a barrel-shaped mold has been designed and refined to produce nearly cylindrical as-compacted cores.

\section{Extrusion of Euel Tubes}

As-compacted $\mathrm{P} / \mathrm{M}$ cores are extruded using either a 520-ton laboratory or 3000-ton production press. The extrusion billet is made by capsulating as-compacted cores in aluminum components. The assembly is evacuated at an elevated temperature to remove gases. This high temperature outgassing operation also sinters the compact, but no reaction between $\mathrm{U}_{3} \mathrm{O}_{8}$ and aluminum has been observed. Before extrusion, the billet is preheated and coated with a graphite-lead-oil lubricant. The tooling temperatures range from $175^{\circ} \mathrm{C}$ to $400^{\circ} \mathrm{C}$ depending on the type of tube being extruded.

\section{In-Line Recycle of Reject Cores and Tubes}

A method of in-line recycle of the ${ }^{235} \mathrm{U}$ from rejected tubes and cores is essential for the $P / M$ process. Mechanical recycle was developed for rejects because $P / M$ compacts or tubes cannot be directly recycled by melting (as used for alloy) and chemical processing is rather costly due to long dissolving times and increased liquid waste generation. 
Laboratory tests have demonstrated that $\mathrm{P} / \mathrm{M}$ cores can be pulverized and recompacted. The pulverized material is ${ }^{10 \%}$ more dense than a powder blend of the same $\mathrm{U}_{3} \mathrm{O}_{8} / \mathrm{AI}$ ratio. Commercial pulverizing equipment can reduce compacts to -80 mesh powder which is satisfactory for recycling. The pulverizer is installed in a special glove box to contain any dust that may be formed during operation.

Four 2-flute, spiral, 0.5-in.-diameter solid carbide cutters are used to chip the core of an oxide tube from which $2 / 3$ of the cladding has been removed. Radiography of a compact containing $18 \%$ chips showed good uniformity. For decladding, a machine has been designed to remove ribs from ribbed tubes $\{2 / 3$ of the cladding is then removed by alkaline etch). The four cutters reduce a ful1-length tube core to chips in $<2 \mathrm{hr}$. The chips are uniform in size (about 3 by 80 by $120 \mathrm{mils}$ ) and only slightly curled.

The final blend for isostatic compaction can tolerate as much as 20 wt \% of the chips. This is an acceptable addition rate because more than $90 \%$ of the products meet specifications.

\section{Charge Calculations}

Charge calculations for a billet core are made using the computer. The computer program determines the amount of $\mathrm{U}_{3} \mathrm{O}_{8}$ and aluminum needed for each tube type and gives an inventory for ${ }^{235} \mathrm{U}$ accountability.

The oxide is received in $10-\mathrm{kg}$ batches each of which may contain a different isotopic content. The program determines the average composition and the amount of high and low enriched material for each core needed to obtain a final blend with the average isotopic composition. Recycled material can also be used in the calculations.

Fabrication of Small Scale $\mathrm{U}_{3} \mathrm{O}_{8}-\mathrm{Al}$ Fuel Tubes

Small scale tubes are used to demonstrate the process capability for powder compaction and extrusion. The model is compared with production-scale tubes in Figure 6 . Thin wall (0.35-in.) billet cores with up to $100 \%$ uranium oxide were successfully compacted in the SRL isostatic press. Scale model cores were initially made in bags with 1 -in.-thick walls, but thinner $(0.25-$ in.) bags had to be used for the small compacts to prevent core breakage when compaction pressure is released. Cores from the thin urethane bags were dimensionally uniform. 


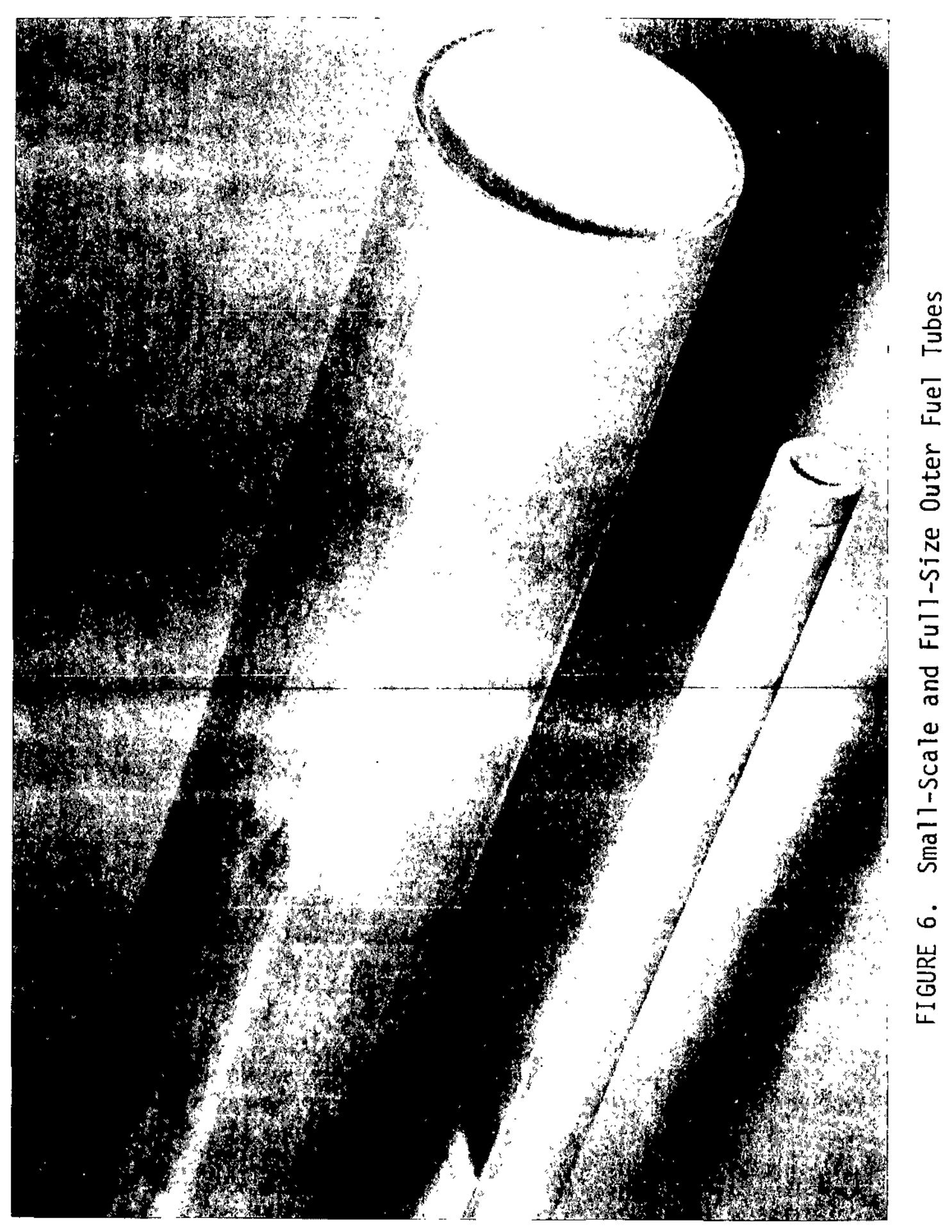


For initial extrusion development, smal1-scale parametric tests are determining the effect of extrusion variables such as die cone angle, tooling temperature, extrusion ratio and ram speed, core composition, and end plug alloy. Two different tube configurations are used: thick wall (with outer cladding/core/ inner cladding thickness of $30 / 70 / 30 \mathrm{mils})$ and thin wa1l $(10 / 20 / 10)$. Both tube sizes with cores of $80 \mathrm{wt} \% \mathrm{U}_{3} \mathrm{O}_{8}$ were successfully extruded in the laboratory extrusion press.

The relationships among die cone angle and tooling temperature, core composition, and extrudability are shown in Figure 7. These variables represent measurable quantities and are parameters for the fabrication process. Tubes are more likely to be free from surface or internal defects at half die cone angles larger than the $45^{\circ}$ and at relatively low extrusion tooling temperature $\left(175^{\circ} \mathrm{C}\right)$. Tests are in progress at even larger die cone angles and with cores containing more $\mathrm{U}_{3} \mathrm{O}_{8}$.

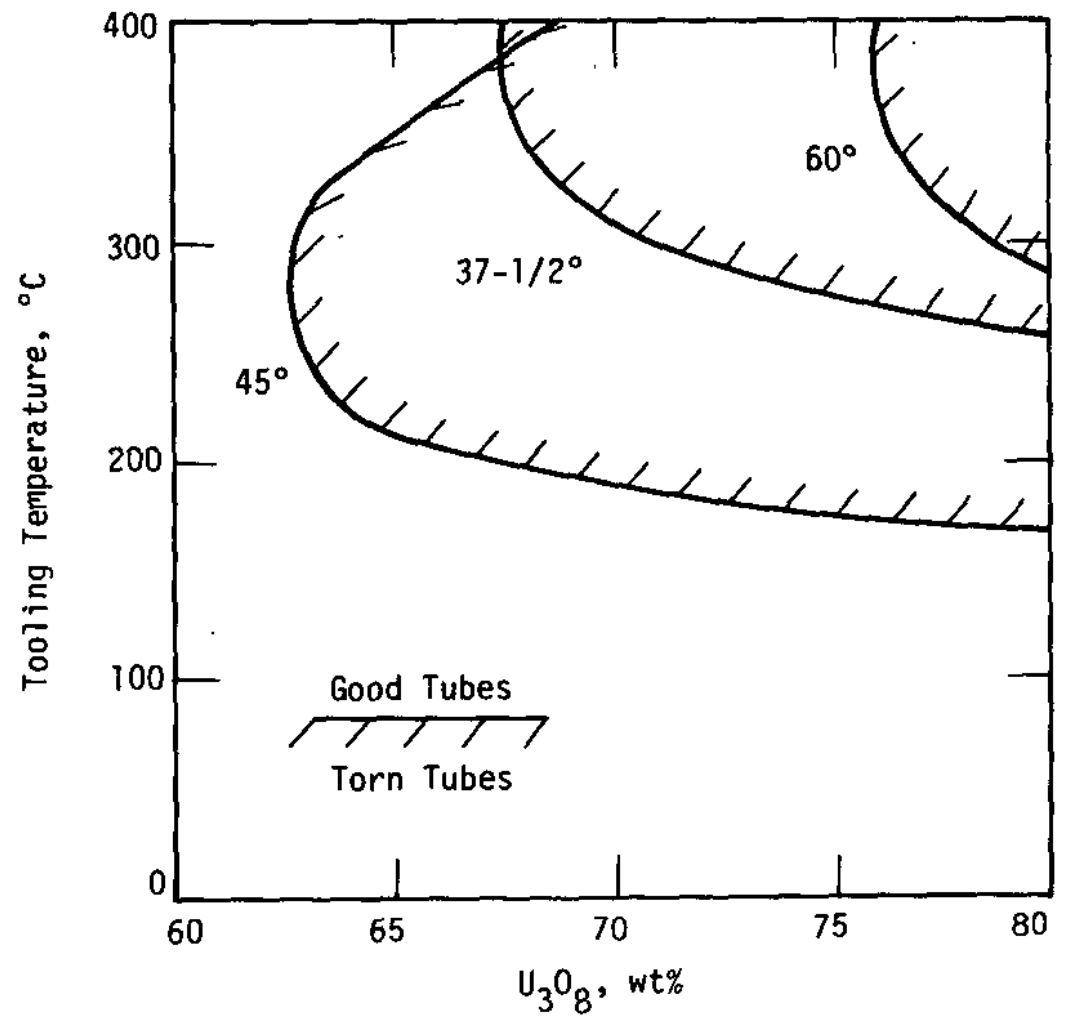

FIGURE 7. Effect of $\mathrm{U}_{3} \mathrm{O}_{8}$ Content, Extrusion Tooling Temperature, and Half the Die Cone Angle on Tube Quality 
Measurements of Extrusion Forces

Extrusion forces are monitored by a transducer on the extrusion press hydraulic system and with a load cell equipped with a strain gauge which measures the force applied to the extrusion die. Results show that the billet-to-container friction is small (approximately $10 \%$ ). Thus, the present lubricants (graphite, lead, and oil) for the billet and container are effective at both low and high extrusion temperatures. As the billet becomes shorter and the billet-to-container friction decreases, the difference in the forces on the stem and the die does not decrease. Therefore, force difference represents primarily internal work in deforming the billet rather than friction between the billet and container.

The force required to extrude small SRL tubes with high $\mathrm{U}_{3} \mathrm{O}_{8}$ concentrations increases at low tooling temperature and with increasing core concentration as shown in Figure 8.

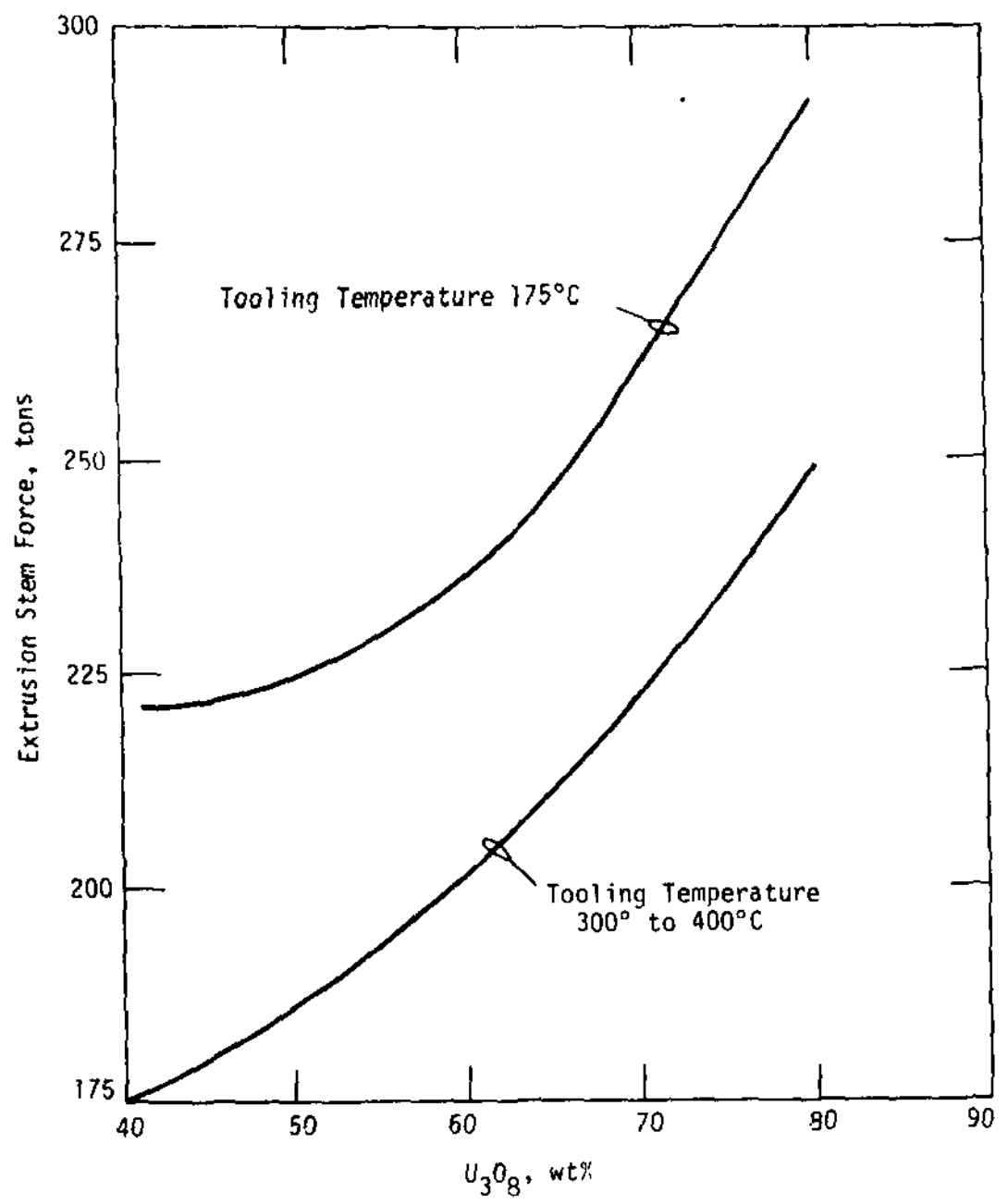

FIGURE 8. Effect of Tooling Temperature and $\mathrm{U}_{3} \mathrm{O}_{8}$ Concentration on Extrusion Force Required 


\section{Cladding Thickness Determination}

The thickness of the cladding over the core in fuel tubes is determined by $x$-ray fluorescence. ${ }^{3}$ The instrument uses $x$-rays from a $100 \mathrm{mCi}{ }^{109} \mathrm{Cd}$ source. The ratio of the uranium $\mathrm{L}_{\beta}$ to $\mathrm{L}_{\alpha}$ peak heights allows determination of the cladding thickness. For 30-35 mils of aluminum cladding, the accuracy is $\pm 1 \mathrm{mil}$. Thicknesses over $35 \mathrm{mils}$ have been measured, but with 1ess accuracy because the $\mathrm{L}_{\alpha}$ peak is severely attenuated by the thicker aluminum.

\section{P/M Irradiation Tests at SRP}

In 1971-72, nine 20-mil clad fuel tubes and 4 ciuplose or partial 3-tube assemblies with $\mathrm{U}_{3} \mathrm{O}_{B}-\mathrm{Al}$ cores were irradiated in three different reactors. These tubes had 18-59 wt \% $\mathrm{U}_{3} \mathrm{O}_{8}-\mathrm{Al}$ cores. Irradiation conditions are given in Table 1. All tubes irradiated well except one tube each of 29.5 and 59 wt $\%$ which developed a small hole in the 20-mil cladding during the latter part of the irradiation. The holes formed in areas of thin cladding which were caused by large or agglomerated $\mathrm{U}_{3} \mathrm{O}_{8}$ particles in the as-fabricated core. Subsequent work has led to a better understanding of process variables and resulted in development of satisfactory techniques for the $\mathrm{P} / \mathrm{M}$ core fabrication process.

The most recent irradiation test of $P / M$ fuel was in 1976-77 when six 3 -tube assemblies with $30 \mathrm{mils}$ of cladding were irradiated to $40 \%$ burnup or $1.6 \times 10^{21}$ fissions/cc of core. The cores contained 46-57 wt $\% \mathrm{U}_{3} \mathrm{O}_{8}$. The irradiation was completed successfully and final inspection and testing showed no defects associated with irradiation of high wt $\% \mathrm{P} / \mathrm{M}$ fue1.

\section{Evaluation of Irradiated $P / M$ Fue}

Maintaining the original dimensions of $\mathrm{U}_{3} \mathrm{O}_{8}-\mathrm{Al}$ powder fuel cores during irradiation is vital to successful reactor operation. Fission gas blistering of cladding and high-temperature reactions in the core are being studied to develop fabrication specifications. Both irradiated and unirradiated tubes from previous tests have been evaluated to characterize process variables that may affect the safety of operating with $\mathrm{P} / \mathrm{M}$ fuel cores.

\section{Fission Gas Blistering}

No blistering or dimensional instability has occurred in plant reactor irradiations of experimental $\mathrm{U}_{3} \mathrm{O}_{8}-\mathrm{Al} \mathrm{P} / \mathrm{M}$ fuel tubes. These tubes, which contained about 18,30 , and $59 \mathrm{wt} \% \mathrm{U}_{3} \mathrm{O}_{8}$, were irradiated over the range of $0.5-1.6 \times 10^{21}$ fissions/cc of core. 


\section{TABLE 1}

SRP Irradiation of $P / M$ Fuel Tubes

\begin{tabular}{|c|c|c|c|c|c|c|}
\hline \multirow[b]{2}{*}{$\begin{array}{l}\text { Number } \\
\text { Irradiated }\end{array}$} & \multicolumn{3}{|l|}{ Wt \% } & \multirow{2}{*}{$\begin{array}{l}\text { Average } \\
\text { Fission } \\
\text { Density } \\
\left(10^{21} / \text { ce Core }\right)\end{array}$} & \multirow[b]{2}{*}{$\begin{array}{l}\text { Max Core } \\
\text { Temp, }{ }^{\circ}{ }^{\circ} \mathrm{C}\end{array}$} & \multirow[b]{2}{*}{$\begin{array}{l}\text { Irradiation, } \\
\text { days }\end{array}$} \\
\hline & 0 & $U_{3} \mathrm{O}_{8}$ & $\begin{array}{l}\text { Fines } \\
(<325 \text { Mesh) }\end{array}$ & & & \\
\hline 5 & 12 & 17.6 & 68 & 0.5 & 195 & 105 \\
\hline 4 & 25 & 29.5 & 68 & 0.7 & 200 & 122 \\
\hline 15 & $33-50$ & $38-59$ & 40 & $1.0-1.6$ & 220 & $140-208$ \\
\hline
\end{tabular}

a. Calculated from reactor operating data using predicted aluminum oxide thickness and measured hot spot factor. 
Heating sections from the irradiated tubes showed that the threshold temperature for blistering depends on exposure and uranium content in the fuel tube as shown in Figure 9. No blistering occurred in any tube except at temperatures at least $175^{\circ} \mathrm{C}$ above the maximum operating temperature for $\mathrm{U}_{3} \mathrm{O}_{8}-\mathrm{Al} \mathrm{P} / \mathrm{M}$ fue 1 $\left(225^{\circ} \mathrm{C}\right)$. Blister thresholds for the $\mathrm{P} / \mathrm{M}$ tubes ranged up to $600^{\circ} \mathrm{C}$, within $60^{\circ} \mathrm{C}$ of the melting temperature of the cladding.

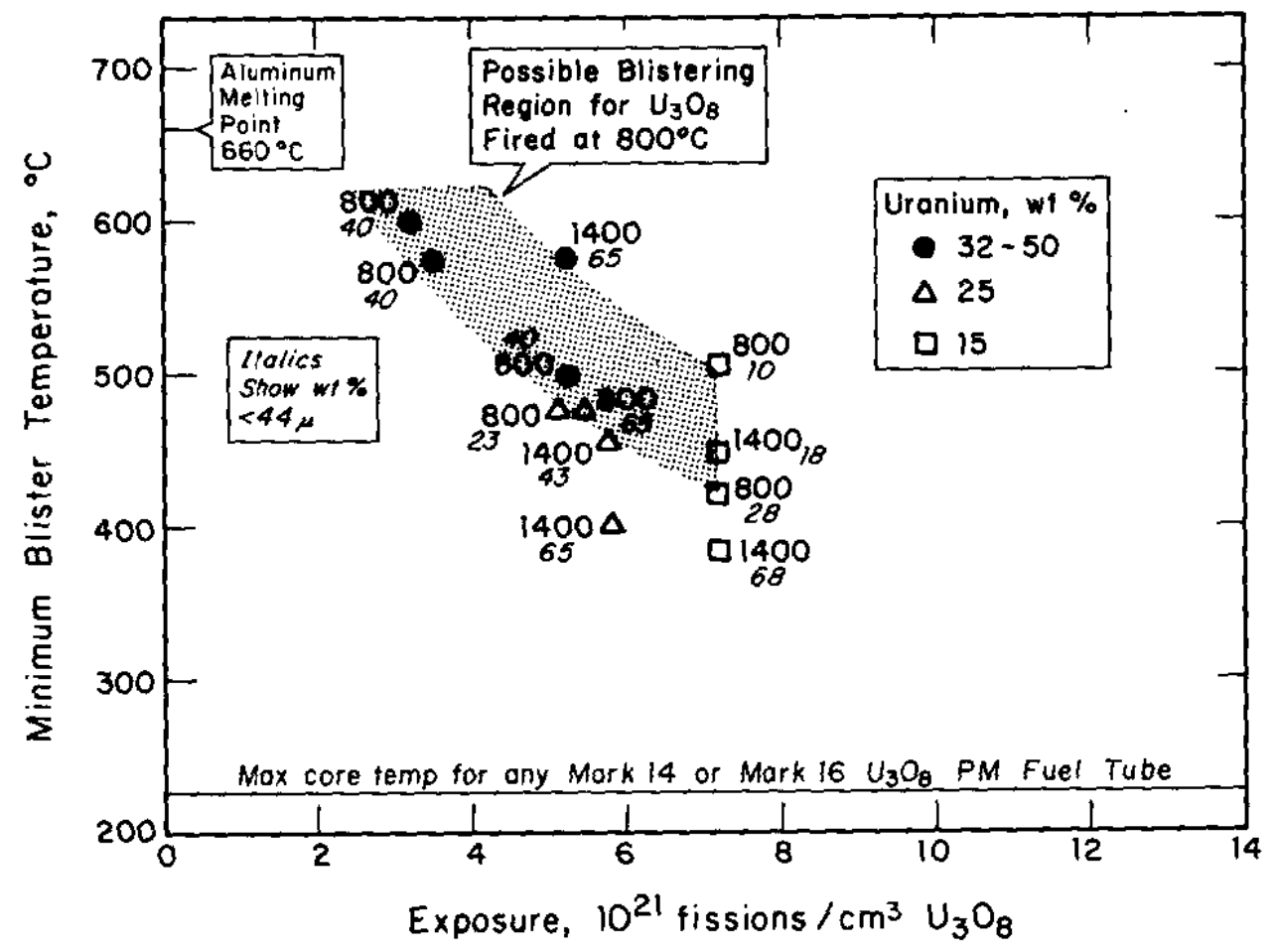

FIGURE 9. Temperatures Required for Blister Formation on Irradiated Fuel Tubes with $\mathrm{U}_{3} \mathrm{O}_{8} \mathrm{P} / \mathrm{M}$ Cores $40 \%$ Burnup 


\section{CONCLUSIONS}

Experimental results thus far indicate that:

- cores containing fine (-325 mesh) $\mathrm{U}_{3} \mathrm{O}_{8}$ and aluminum powders can be made practically free of high-density areas during the outlined $\mathrm{P} / \mathrm{M}$ preblending and sieving techniques.

- $\mathrm{U}_{3} \mathrm{O}_{\mathrm{B}}-\mathrm{Al}$ cores can be isostatically compacted with up to $100 \mathrm{wt}$ $\% \mathrm{U}_{3} \mathrm{O}_{8}$ and tubes successfully extruded to 80 wt $\%$ oxide.

- fission gas blistering of $\mathrm{U}_{3} \mathrm{O}_{8}-\mathrm{Al} \mathrm{P} / \mathrm{M}$ tubes as indicated by the blister tests is a function of fissions/cc of $\mathrm{U}_{3} \mathrm{O}_{8}$ in the core. Decreasing the fission density of oxide increases the threshold temperature for blister formation.

- $\mathrm{U}_{3} \mathrm{O}_{8}-\mathrm{Al} \mathrm{P} / \mathrm{M}$ tubes with up to 59 wt $\% \mathrm{U}_{3} \mathrm{O}_{8}$ have been successfully irradiated in SRP reactors to $1.6 \times 10^{22}$ fissions/cc of core or $\sim 7 \times 10^{20}$ fissions/cc of $\mathrm{U}_{3} \mathrm{O}_{8}$.

- small-scale metal forming tests sufficiently mock up production operations so that variables can be initially tested in the laboratory.

- parametric metal forming studies show a relationship between measurable variables of tooling temperature, half die angle and core composition on extruded tube quality. Lower temperatures and larger die angles $\left(50-60^{\circ}\right)$ favor extrusion of highdensity fuel tubes. 


\section{REFERENCES}

1. Aronin, L. R. and Geary, A. L., Hot Extmusion of Metal Powders, NMI-IJ-29, August 9, 1960.

2. Harwood, C. F. and Walanski, K. R., Monitoring the Mixing of Powders, Paper presented at the American Chem. Soc. 166th National Meeting, Chicago, Illinois, August 26-31, 1973.

3. Slates, R. V. and Stewart, W. E., Measurement of Reactor Tube Cladding Thickness by X-ray Fluorescence Spectrometry, DP-1465. 